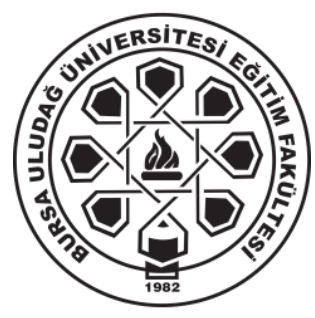

Bursa Uludağ Üniversitesi

Ĕ̆itim Fakültesi

Dergisi

Araştırma Makalesi

https://dx.doi.org/10.19171/uefad.679330

Başvuru/Received: 20.03.2019 Kabul/Accepted: 04.11.2019

\title{
Öğrencilerin Yazma Kaygıları ve Eğilimlerine İlişkin Öğretmen Görüşleri ${ }^{1}$
}

\author{
Hacer DENIZ \\ Doktora ögrencisi, Fırat Üniversitesi Türkçe Eğitimi Bilim Dalı \\ hcrdnzzz@gmail.com, \\ OrcID: 0000-0002-2604-1893 \\ Sezgin DEMIR \\ Doç. Dr., Firat Üniversitesi, Eğitim Fakültesi, \\ Türkçe ve Sosyal Bilimler Eğitimi Bölümü \\ sezgin.demir@firat.edu.tr, \\ OrcID: 0000-0002-0466-2218
}

\section{ÖZET}

Yazma eğitimini olumsuz etkileyen durumlardan biri olarak yazma kaygısı, öğrencilerin yazma beceri gelişimini engellemektedir. Yazma eğilimi yazma ilgi ve isteğiyle becerinin kullanılma oranıdır. Dolayısıyla yazma becerisinin kazanımı, gelişimi ve alışkanlık hâline getirilmesi yazma kaygısıyla olduğu kadar yazma eğilimiyle de ilişkilidir. Çalışmanın amacı; Türkçe öğretmenlerinin, öğrencilerin yazma kaygıları ve eğilimlerine ilişkin görüşlerinin tespit edilmesidir. Nitel desenlerden fenomenolojik türde gerçekleştirilen araştırmada veriler, içerik analizi

1 Bu çalışma, 2018 Kasım ayı içerisinde tamamlanan "Öğrencilerin Yazma Kaygılarının Yazma Eğilimleriyle İlişkisi” adlı yüksek lisans tezinden hareketle hazırlanmıştır. Ayrıca çalışma, 18-20 Nisan 2019 tarihinde Alanya Alaaddin Keykubat Üniversitesinde gerçekleştirilen VI. ASOS Congress Uluslararası Eğitim Bilimleri Sempozyumu'nda sözlü bildiri olarak sunulmuştur. 
yöntemiyle çözümlenmiştir. Aşamalı ve amaçlı örnekleme yöntemiyle gönüllülük esasına dayalı belirlenen çalışma grubu, Elazığ il merkezinde görev yapan 12 Türkçe öğretmeninden oluşmaktadır. Yüz yüze gerçekleştirilen görüşmelerde araştırmacılar tarafından yarı yapılandırılmış olarak geliştirilen görüşme formu kullanılmış, frekans dağılımlarına göre tablolaştırılan bulgular alan yazın doğrultusunda yorumlanmıştır. Sonuç olarak öğretmen, aile ve akran tutumu, kullanılan yöntem ve teknikler, özgüven, eğitim sistemi ve metin türünün yazma kayg1 ve eğilim düzeylerinde etkili olduğu, öğrencilerin yazma kaygıları arttıkça eğilimlerinin azaldığı söylenebilir.

Anahtar Sözcükler: Ana dili eğitimi, Türkçe eğitimi, yazma eğilimi, yazma eğitimi, yazma kaygısı.

\title{
Teachers' Opinions on Students' Writing Anxiety and Dispositions
}

\begin{abstract}
Writing anxiety is one of the factors that negatively affect writing education prevents students' writing skill development. Writing tendency is defined as the rate of the use of the skill with interest and desire. Therefore, the acquisition, development and habit of writing skills are related to writing anxiety, in addition to writing disposition. This study aims to determine the opinions of Turkish teachers about the writing anxiety and tendencies of students. In this qualitative, phenomenological study, data were analyzed by content analysis method. The study group was determined on a voluntary basis using the progressive and purposive sampling method and consisted of 12 Turkish teachers working in Elazığ city center. In the face-to-face interviews a semi-structured interview form which was developed by the researchers was used, and the tabulated results according to the frequency distributions was interpreted according to the literature. Findings showed that teachers, family and peer attitudes, methods and techniques used, self-confidence, education system and text type could be effective in writing anxiety and disposition levels. In conclusion, students' tendencies to write decrease as writing anxiety increases.
\end{abstract}

Key Words: Mother tongue education, Turkish education, writing disposition, writing education, writing anxiety. 


\section{GíRiş}

Yazma becerisi çok yönlü düşünmeye yönlendiren bir yaratma sürecidir. Geniş bilgi ve beceri gerektiren yazma, araştırma ve bilgi edinme yollarının etkin kullanımını içermekte, öğrencilerin merak ve keşfetme duygularını canlı tutmakta, araştırma becerilerini desteklemektedir. Yazma; fikir üretme, bu fikirleri organize etme, metni biçim ve içerik açısından düzenleme ve yayımlama aşamalarını içeren bütünsel bir üretme sürecidir (Sundem, 2007, s. 41). Dolayısıyla yazma sürecinin her basamağı yoğun bilişsel işlemleri içermesi ve bu işlemlerin yazma sırasında çeşitli duyuşsal, devinsel becerilerle birlikte kullanılması nedeniyle yazma becerisi, beyin gelişimini önemli ölçüde desteklemektedir. Yansitıcı ve eleştirel düşüncelerin gelişiminde etkili olan yazma, aynı zamanda yansıtıcı ve eleştirel düşünme becerilerini gerektirmektedir (Williams, s. 43, 2003). Buna ek olarak yazma, bireyin kişiye has ürün elde etmesini sağlayarak kişilik gelişimini desteklemektedir. Düşüncelerin planlı ve düzenli yazılması zevk duyarak yazmayı sağlamakta (Par, 2007, s. 16), yazma ilgi ve isteğini artırmakta, bireye sanatsal ve estetik açıdan duyarlılık kazandırmaktadır. Bu durum ise yazma alışkanlığı ve devamlılığını sağlayarak yazar olma isteğini desteklemektedir. Yazma, düşünce ufkunun gelişimini, anlatım güzellikleri ve ifade kalıplarının öğrenilmesini sağlamaktadır (Cemiloğlu, 2001 s. 4). Tüm bu becerilerle yakından ilişkili olan yazma becerisinin gelişimi etkili bir yazma eğitimine bağlıdır.

Yazma kayg1s1, öğrencilerin yazma gelişimini engellemektedir. Yazmaya karşı duyulan yüksek kayg1, öğrencilerin düşüncelerini anlamlı ve tutarlı şekilde okunaklı bir yazıyla kâğıda aktarmalarına engel olmakta; düşük kaygı ise öğrencilerin yazmaya karşı güdülenmelerini azaltabilmektedir. Bu durum; özgüven ve motivasyon eksikliğine, mantık dış1 düşüncelerin geliştirilmesine, yazmaya karşı olumsuz tutum geliştirme ve yazmaktan kaçma davranışlarına neden olmaktadır. Bu noktada yazmaya karşı duyulan kaygı düzeyiyle öğrencilerin yazma eğilimleri arasında bir ilişki belirmektedir.

Yazma becerisinin kazanım ve gelişimi; yazma bilgisine değil, yazma işleminin gerçekleştirilmesine (Akyol, 2015) ve becerinin devaml kullanılmasına bağlıdır. $\mathrm{Bu}$ noktada yazma eğilimi kavramı ortaya çıkmaktadır. Çünkü yazma eğilimi yazma ilgi ve isteğiyle becerinin kullanılma oranıdır. Dolayısıyla yazma becerisinin kazanımı, gelişimi ve alışkanlık hâline getirilmesi yazma kaygısıyla olduğu kadar yazma eğilimiyle de ilişkilidir. Yazma kaygı ve eğilimi arasındaki ilişkinin belirlenmesine yönelik nicel araştırmalar yapılmıştır (Berk, 2014, s. 50; 
Çocuk, Yelken ve Ö. Özer, 2016). Ancak bu problemi öğretmenlerin görüşlerinden yola çıkarak aydınlatmaya çalışan nitel bir çalışma gerçekleştirilmemiştir. Bu çalışmanın amacı, Türkçe öğretmenlerinin, ortaokul öğrencilerinin yazma kaygılarıyla yazma eğilimlerinin yazma gelişimlerine yansımalarına ilişkin gözlem, görüş ve deneyimlerinin belirlenmesidir. $\mathrm{Bu}$ ana amaç doğrultusunda yazma kaygısının ve eğiliminin nedenleri, etkileri ve birbirleriyle ilişkisi, metin türüne göre kaygı durumu aydınlatılmaya çalışılmıştır.

\section{YÖNTEM}

$\mathrm{Bu}$ çalışma nitel araştırma desenlerinden olgubilimsel (fenomenolojik) türde gerçekleştirilmiştir. Çalışmada bire bir görüşme yöntemiyle elde edilen veriler, içerik analizi yöntemiyle çözümlenmiştir. Felsefe ve psikolojiye dayanan bu araştırmalar, güven ve empatiye bağl1 görüşmeler yardımıyla bir fenomenle ilgili yaşantıların ortak anlamının betimlenmesini sağlamaktadır (Creswell, 2016b; Creswell, 2016a; Büyüköztürk ve ark, 2017). Açık uçlu mülakatlar, doğrudan gözlem ve yazılı doküman çözümlemesi olmak üzere üç temel yönteme sahip olan nitel araştırmalar; insanların deneyim ve algılarının içerik analiziyle belirlenmesini amaçlar (Patton, 2014).

\section{Çalışma grubu}

Araştırmanın nitel boyutu kapsamında yer alan çalışma grubu aşamalı ve amaçlı örnekleme yöntemi kullanılarak oluşturulmuştur. Türkiye'de devlet ortaokullarında görev yapan Türkçe öğretmenleri araştırmanın evrenini oluşturmaktadır. Bu evren içerisinde Elazı̆ il merkezinde görev yapan Türkçe öğretmenleri alt evren olarak belirlenmiş, böylece hedef evren belirlenerek ulaşılabilirlik sağlanmıştır. Çalışma grubu, hedef evrendeki Türkçe öğretmenleri içinden gönüllülük esası temel alınarak oluşturulmuştur. Nitel araştırmalardaki sosyal süreçlerin rastlantısal örneklemle yorumlanamayacak şekilde bir mantığ 1 ve bağlamı olmasından dolayı amaçlı örnekleme yöntemi kullanılmış (Miles ve Huberman, 2016, s. 27), araştırmacılar tarafından yeterli veri toplandığına kanaat getirilene kadar yeni görüşme yapılmaya devam edilmiş ve katılımcılardan yeni görüşler gelmediği kanaatine varıldığı 9. katılımcıdan sonra 3 kişi ile daha görüşülmüş, katılımc1 görüşlerinin tekrar ettiği 12. katılımcıyla çalışma grubu tamamlanmıştır. Görüşme tekniği kullanılan araştırmalarda, çalışma grubunun büyüklüğü değil, örneklemin ihtiyaç duyulan bilgi miktarını karşılayıp karşılamadığı önemlidir (Türnüklü, 2000). 
Tablo 1. Katılimcilara ait bilgiler

\begin{tabular}{|c|c|c|c|}
\hline & & $\mathbf{n}$ & $\%$ \\
\hline \multirow{2}{*}{ Cinsiyet } & Kadın & 6 & 50 \\
\hline & Erkek & 6 & 50 \\
\hline \multirow{2}{*}{ Eğitim durumu } & Lisans & 9 & 75 \\
\hline & Yüksek lisans & 3 & 25 \\
\hline \multirow{2}{*}{ Unvan } & Öğretmen & 7 & 58.33 \\
\hline & Uzman öğretmen & 5 & 41.66 \\
\hline \multirow{3}{*}{ Hizmet süresi } & $1-10 \mathrm{y} 11$ & 3 & 25 \\
\hline & $11-20$ y1l & 4 & 33.33 \\
\hline & 21 y1l ve üstü & 5 & 41.66 \\
\hline
\end{tabular}

Çalışma 2018 yılında devlet okullarında aktif olarak çalışan 6 kadın, 6 erkek olmak üzere toplam 12 Türkçe öğretmeni üzerinden gerçekleştirilmiştir.

\section{Veri Toplama Araçları}

Ortaokul öğrencilerinin yazma kaygılarıyla yazma eğilimleri hakkında öğretmen görüşlerinin belirlenmesi için yarı yapılandırılmış 11 sorudan oluşan görüşme formu veri toplama aracı olarak kullanılmıştır. Yüz yüze görüşmeyle gerçekleştirilen çalışmalar; katılımcıların düşünce, tutum ve davranışlarıyla bunların olası nedenlerinin öğrenilmesi için yapılmaktadır (Karasar, 2009). Geniş bir alan yazın taraması yapılarak oluşturulan farklı boyutları yansıtan yarı yapılandırılmış 15 maddenin kapsam geçerliğini sağlamak adına devlet okullarında aktif çalışan 5 Türkçe öğretmeninin, ardından Fırat ve Uludağ üniversitelerinde Türkçe eğitimiyle psikolojik danışmanlık ve rehberlik bilim dallarında aktif görev yapan 5 öğretim üyesinin görüş ve değerlendirmelerine sunulmuştur. Alınan görüşler doğrultusunda taslak form üzerinde değişiklikler yapılmış, görüşme formu elde edilmiştir.

\section{Görüşme Süreci}

Çalışmada gönüllülük temel alınmış, ek sorular sorularak yarı yapılandırılmış bire bir görüşmeler gerçekleştirilmiştir. Bağımsız düşündürebilmeyi amaçlayan açık uçlu sorulardan yararlanılarak uygulanan görüşmeler ses kayıt cihazıyla kayıt altına alınmıştır. Çalışmanın "inandırıcılığını" sağlayabilmek amacıyla yazılı belge hâline getirilen görüşler, katılımcılara kontrol ettirilmiş ve düzeltmelerine, görüş 
değiştirmelerine, eklemeler yapmalarına fırsat tanınmıştır. Katılımcılara araştırmanın amaçları, süreci, verilerin bilimsel amaç dışında kullanılmayacağı güvencesi vb. hakkında bilgi verilerek çalışmanın "aktarılabilirliğinin" artırılması amaçlanmıştır.

\section{Verilerin Analizi}

Veriler, yazılı olarak bilgisayar ortamına aktarılmış, betimsel analiz yöntemiyle analiz edilmiştir. Veri analizi; alan yazın doğrultusunda kodlama yapmayı ve seçilen kodları temalar altında gruplandırmayı içermektedir (Creswell ve Plano Clark, 2015). Gerçekleştirilen kategorilerin/ sınıflandırmanın katılımcı görüşleri ve alan yazınla uyumu gözetilerek "kategori netliği" sağlanmaya çalışılmıştır (Bilgin, 2014; Sönmez ve Alacapınar, 2016). Benzer cevaplar bir araya getirilmiş, cevapların toplam cevaplar içindeki frekansı tablolaştırılarak yorumlanmıştır. Verilerin analizinde NVivo 8 programı kullanılmıştır.

\section{Geçerlik, Güvenirlik ve Etik}

“Kodlayıcı güvenirliği”ni sağlayabilmek için aynı araştırmacı tarafindan farklı zamanlarda -30 gün arayla- kodlanarak iki kodlama arasındaki uyumun ilk etapta \%70'in üzerinde olması amaçlanmıştır (Miles ve Huberman, 2016). Kodlayıcı güvenirliğinin hesaplanmasında Miles ve Huberman'ın (2016) "Güvenirlik=Görüş Birliği / Toplam Görüş Birliği + Görüş Ayrılı̆̆g”" formülünden yararlanılmış, ilk etapta $(805 / 805+184=.81)$ \%81 değerinde hesaplanan kodlayıcı güvenirliği yeterli bulunmuştur. Her görüşme sonunda araştırmacı verilere yönelik kodlama işlemini gerçekleştirmiş ve bir sonraki görüşme için hazırlık yapmıştır (Miles ve Huberman, 2016).

\section{BULGULAR VE YORUM}

$\mathrm{Bu}$ bölümde araştırmanın nitel boyutuna ilişkin içerik ve betimsel analiz sonucunda elde edilen bulgulara yönelik kodlar, kodlara yönelik frekanslar tablolaştırılarak alan yazın ışığında yorumlanmıştır. 
Tablo 2. Katılımcıların "metin türü özelinde öğrencilerin yazma kayg1 düzeyleri” hakkında görüşleri

\begin{tabular}{lccc}
\hline Metin türü & \multicolumn{1}{c}{} & \\
\hline Öyküleyici yazılar & Olumlu & Olumsuz & Toplam \\
Türlere yönelik bilgi eksikliği & 38 & - & 38 \\
Düşünce yazıları & - & 18 & 18 \\
Bilgilendirici yazılar & 2 & 31 & 33 \\
Şiirr & 4 & 17 & 21 \\
Kurala dayalı yazma & 9 & 8 & 17 \\
Serbest türde yazma & - & 7 & 7 \\
Öğretici metinler & 5 & - & 5 \\
Toplam & - & 2 & 2 \\
\hline
\end{tabular}

Öyküleyici metinlerin, öğrencilerin yaşanmış veya yaşanabilir olaylardan yararlanmalarını, olaylarının akışına göre metne daha kolay yön verebilmelerini ve hayal dünyalarını etkin olarak kullanabilmelerini sağladığına değinilmiştir. Öğrencilerin bazı türleri kavrayamadıkları için nasıl yazacakları konusunda telaşa kapıldıkları belirtilmiştir. Yazılacak tür hakkındaki bilgi eksikliği ve türün gerektirdiği kurallar bunun nedeni olabilir. Bilgilendirici ve düşünceye dayalı yazılar, konu hakkında birikime sahip olma, okuyucuları düşünmeye yöneltebilme, gelişmiş gözlem ve farkındalığa sahip olmayı gerektirmesiyle yazmayı zorlaştırabilmektedir. Şiir konusunda öğrencilerin yazmaya istekli oldukları ve bazı kelimelerin uyumundan yararlanarak ahenk oluşturmayı sevdikleri, ancak kurallar doğrultusunda estetik dil kullanımında zorlandıkları belirtilmiştir. Öğrenciler, öyküleyici türlerle daha çok karşılaştıklarından bu türde yazarken daha az kaygılandıkları bildirilmiştir.

K.1. Çocuklar genel olarak metinlerde tabii ki metin türüne dair eğer bilgileri yoksa bu onları çok kaygılandırıyor. Neden? Eğer siz derseniz çocuğa bir konu hakkında bir makale yazın çocuk önce makalenin ne olduğunu algılamakta zorlanıyor. Zaten çocuklar özellikle bilgilendirici metin türünde yazmakta zorlanıyorlar.

K. 11. Yani düşünce yazılarında birazcık sıkıntı çekiyoruz hikâyede daha rahatlar, hatta çok istekliler şiirde de hakeza ama düşünce yazılarında maalesef ilerleme kaydedemiyor. Bu da dediğim gibi hani kafada yeterince kelime olmadığ 1 için kendi de biliyor aynı şeyleri tekrar ettiğini, arkadaşlarının dalga geçmesinden öğretmenin kızmasından korktuğu için paylaşmak istemiyor. 
Tablo 3. Katılımcıların “öğrencilerin yazma ve diğer dil becerilerine yönelik motivasyonları” hakkında görüşleri

\begin{tabular}{lccc}
\hline Yazma motivasyonu & & $\boldsymbol{f}$ & \\
& Olumlu & Olumsuz & Toplam \\
\hline Yazma & 4 & 24 & 28 \\
Konuşma & 11 & 8 & 19 \\
Okuma & 11 & 4 & 15 \\
Yazma tutumu & 1 & 13 & 14 \\
Yazma işlemleri & - & 8 & 8 \\
Dinleme & 6 & - & 6 \\
Okuma alışkanlığ1 & 4 & 2 & 6 \\
Temel dil becerileri & 1 & 4 & 5 \\
Anlatma becerileri & - & 4 & 4 \\
Sinav odaklı sistem & - & 4 & 4 \\
Yazı türü değişikliği & - & 2 & 2 \\
Toplam & $\mathbf{3 8}$ & $\mathbf{7 3}$ & $\mathbf{1 1 1}$ \\
\hline
\end{tabular}

Katılımc1 görüşleri; öğrencilerin dinleme, konuşma ve okuma becerilerine göre yazmaya motive olmakta zorlandikları konusunda yoğunlaşmaktadır. Çünkü yazma amacının ve konusunun belirlenmesi, konu ve tür doğrultusunda ön hazırlık çalışmaları gibi işlemler öğrencilerin yazmada diğer dil becerilerine oranla daha çok zorlanmalarına neden olmaktadır. Yazmaya yönelik olumsuz tutumun, yazma eğilimini olumsuz yönde etkilediği belirtilmiştir. Öğretmenin yazı türü konusundaki yanlış tutum ve uygulamaları yazmaya yönelik tutumu olumsuz etkileyebilmektedir. Öğrencilerin benzer karmaşı zihinsel süreçleri içeren konuşmayla yazmada zorlandıkları, ancak yazmanın yapay dil becerisi olması nedeniyle konuşmaya daha istekli oldukları söylenebilir. Nitekim benzer bir durum okumayla dinleme arasında vardır. Ayrıca eğitim sisteminin sınava dayalı olması nedeniyle özellikle 8. sınıfların dil gelişimlerini sağlayacak etkinliklerin uygulanamadığı ve öğrencilerin test çözme eğiliminde oldukları söylenebilir.

K.4. Ya şimdi konuşma da bazı öğrenciler çok aktif mesela çok katılıyorlar yani bir şeye, özellikle kitap okuyan öğrenciler çok aktifler, yorum yapmak, konuşmak istiyorlar, düşüncelerini almak istiyorlar. Mesela biz öğrencilerimizi serbest bırakıyoruz yani yanlış bile olsa söyleyin, yorumlarınızı öğrenmek istiyoruz.

K.5. Değişim olabiliyor, dinleme, okuma, sorulara cevap verme şeyindeki motivasyonları daha iyi ama yazma etkinliklerinde zayıflar. Bunda da eğitim sisteminin etkili olduğu düşüncesindeyim. Bu son y1llardaki teste dayalı eğitim sistemi maalesef öğrencileri sözlü ve 
yazılı anlatma becerilerini donduruyor. Tabii yazabilmek için okumak lazım.

Tablo 4. Katılımcıların "Öğrencilerin yazma kaygılarının gözlenebilen etkileri" hakkında görüşleri

\begin{tabular}{lccc}
\hline Yazma kaygısının fiziksel etkileri & & $\boldsymbol{f}$ & \\
& Olumlu & Olumsuz & Toplam \\
\hline Fiziksel dişa vurum & - & 14 & 14 \\
Kaçma eğilimi & - & 13 & 13 \\
Özgüven & - & 5 & 5 \\
Yazma isteği & - & 5 & 5 \\
Baskı hissetme & - & 4 & 4 \\
Mantık diş1 otomatik düşünceler & - & 4 & 4 \\
Yazma becerisinin zorluğu & - & 4 & 4 \\
Paylaşma & - & 3 & 3 \\
Yazmaya başlayamama & - & 3 & 3 \\
Geleneksel disiplin anlayışı & - & 2 & 2 \\
Pozitif disiplin anlayışı & 2 & - & 2 \\
Toplam & $\mathbf{2}$ & $\mathbf{5 7}$ & $\mathbf{5 9}$ \\
\hline
\end{tabular}

Yazma kaygısının etkilerine yönelik görüşler; öğrencilerin yazma kaygılarını fiziksel olarak titreme, baş ağrısı, kızarma, mide bulantısı gibi şekillerde dışa vurdukları konusunda yoğunlaşmaktadır. $\mathrm{Bu}$ durum öğrencilerin yazma konusunda oldukça kaygılı olduklarının yansımasıdır. Öğrencilerin yazma kaygıları genellikle yazmaktan kaçınmalarına veya yazmaya başlayamamalarına neden olmaktadır. Yazma konusunda yaşanılan kaygının, yazmaya yönelik tutumu olumsuz etkilediği söylenebilir. Mantık dış1 otomatik düşüncelerin ve özgüven eksikliğinin yazma kaygısın1 yükselttiği söylenebilir. Ancak yazma kaygıs1, özgüven eksikliğinin bir sonucu olduğu gibi nedeni de olabilir. Yazma becerisinin zorluğu ve geleneksel disiplin anlayışı, yazma kaygısını artırabilmektedir. Ancak ögretmenin pozitif disiplin anlayışını benimsemesi yazma kaygısının aşılmasında etkilidir.

K.11. Yani bunlar da oluyor, bunun dışında bahaneler, kalem mesela ucu kırıldı, ucu olduğu hâlde gidip onunla uğraşıyor, çantasını karıştırıyor, geç kaldım diyor, hani kötü yazıyor, geç kalıyor başka bir sebebe bağlıyor bunu. Duymadım, şöyle yaptım, sürekli geri kalıyor sonra yazarım getiriyor lafi o tarz hatalar, o tarz şikâyetler çok oluyor.

K.5. Tabii şimdi hep ödevleri kontrol ettiğimizde öğrencilerde en zorlandığı etkinlik efendim yazma çalışması. Sözlük çalışması rahat yapıyorlar, metne dayalı sorulara cevap verebiliyorlar, ama en zoru dil 
bilgisi konularını hakeza yapabiliyorlar ama kompozisyon yazma çalışmalarında öğrenciler zorlanıyorlar. Tabii alışık olmadıkları için bir gayret göstermeleri gerektiğinden zorlanıyorlar.

Tablo 5. Katılımcıların "yazma kaygısına çözüm yolları” hakkında görüşleri

\begin{tabular}{lccc}
\hline Yazma kaygısına çözüm yolları & Olumlu & $\begin{array}{c}\boldsymbol{f} \\
\text { Olumsuz }\end{array}$ & Toplam \\
\hline Yönlendirme & 18 & - & 18 \\
Motivasyon & 16 & - & 16 \\
Yöntem ve teknikler & 14 & - & 14 \\
Destekleme & 9 & - & 9 \\
Özgürlükçü öğretmen tutumu & 9 & - & 9 \\
Telkin & 9 & - & 9 \\
Öğrenci isteği & 6 & - & 6 \\
Pekiştireç & 6 & - & 6 \\
Okuma çalışmaları & 5 & - & 5 \\
Öğretmen-aile işbirliği & 5 & - & 5 \\
Baskı & - & 4 & 4 \\
Rol-model & 4 & - & 4 \\
Öğretmen-öğrenci iletişimi & 2 & - & 2 \\
Toplam & $\mathbf{1 0 3}$ & $\mathbf{4}$ & $\mathbf{1 0 7}$ \\
\hline
\end{tabular}

Öğrencilerin yazma kaygılarına çözüm yolları hakkında en çok görüş tümü olumlu olma üzere yönlendirme hakkındadır. Öğrencilerin doğru yönlendirilmeleri ve anında dönüt almaları yazma gelişim ve eğilimlerini desteklemektedir. Çünkü ailenin ve öğretmenlerin desteği, telkin edici konuşmaları, verdikleri ödüller, özellikle beğenilme ve kabul edilme duygusunu artıracak sosyal pekiştireçler öğrencilerin yazma kaygılarının aşılmasında etkilidir. Öğrencilerin kendilerini rahatça ifade edebildiği sınıf ortamı ve olumlu öğrenci-öğretmen iletişimi yazma kaygısını azaltırken yazma eğilimini artırabilmektedir. Ayrıca yazma kaygısını aşmak adına öğretmen-veli işbirliğinin olumlu yansımaları olduğu söylenebilir. Çünkü ögretmenin veya ailenin baskıc1, otoriter tutumu yazma kaygısını tetikleyebilmektedir. Okuma ve dinleme becerileri; harflerin ve kelimelerin doğru yazımını desteklemekte örnek metin türleri ve farklı ifade yapılarıyla yazma becerisini geliştirmektedir. Yazma sırasında kullanılan yazma yöntem ve teknikleri sayesinde yazma kaygısı aş1labilmektedir.

K.6. Tabii, hata yapmaktan korkmayın diyoruz. Sinıfta hata yapmanı normal olduğunu, sınıftaki arkadaşlarının da kendi düzeylerinde olduğunu efendim söylüyoruz. Yaptıkları hatalarda onları rencide etmiyoruz. Sınıfın bir idman alanı olduğunu, gerçek yaşamın dışarıda olduğunu, buranın antrenman yeri olduğunu, antrenmanda da 
korkulmaması gerektiğini öğretiyoruz. Onları rahatlatıcı telkinlerde bulunuyoruz.

K.12. Tabii yazmak için özellikle öğrencilere ben bolca kitap okumaları gerektiğini söylüyorum. Önemli yazarları okumadan zaten hani yazmanın temelini alamayacaklarını söylüyorum. Kayg1 konusunda da hani bu sizin kendi yazınız, hani sınıftaki arkadaşınız sadece duyacak bunu alıp basına yansıtılacak bir şey yok, milyonlar bunu görmeyecek...

Tablo 6. Katılımcıların "öğrencilerin yazma kaygılarına neden olan faktörler" hakkında görüşleri

\begin{tabular}{lccc}
\hline Yazma kaygısının nedenleri & Olumlu & $\begin{array}{c}f \\
\text { Olumsuz }\end{array}$ & Toplam \\
\hline Anne-baba tutumu & 7 & 13 & 20 \\
Öğretmen tutumu & 7 & 8 & 15 \\
Aile desteği & 8 & 6 & 14 \\
Özgüven & 1 & 13 & 14 \\
Sosyoekonomik düzey & 6 & 7 & 13 \\
Mantık dişı otomatik düşünceler & - & 11 & 11 \\
Model alma & 6 & 3 & 9 \\
Sosyokültürel etkinlikler & 9 & - & 9 \\
Okuma alışkanlığı & 1 & 7 & 8 \\
Yazma tutumu & 2 & 5 & 7 \\
Demokratik sınıf & 6 & - & 6 \\
Teknoloji & - & 6 & 6 \\
Psikopatoloji & - & 3 & 3 \\
Toplam & $\mathbf{5 3}$ & $\mathbf{8 2}$ & $\mathbf{1 3 5}$ \\
\hline
\end{tabular}

Öğrencilerin yazma kaygılarının nedenlerine yönelik en çok, baskıcı-otoriter, tutarsız, aşırı koruyucu anne-baba tutumlarının yazma kaygısının artmasına; aşırı hoşgörülü anne-baba tutumlarının kaygısızlığa, umursamazlığa neden olduğuna değinilmiştir. Öğretmen, aile ve akranların olumlu model olması, yazma kaygısını düşürerek yazma becerisini desteklemektedir. Öğretmenin demokratik tutumu, öğrencilerle olumlu iletişimi, derste kullandığı etkili yöntem ve teknikler yazma kaygısını azaltabilmektedir. Sosyal ve kültürel etkinliklere katılan öğrencilerin, daha fazla ön bilgiye sahip olmaları nedeniyle yazma konusunda başarılı ve istekli oldukları belirtilmiştir. Bu doğrultuda öğrencilerin okuma alışkanlığına sahip olması, yazma kaygısını azaltacak önemli faktörlerdendir. Öğrencilerin arkadaşlarım bana gülecek, öğretmenim yazdıklarımı aptalca bulacak gibi sanıları, özgüven eksiklikleri, düşük sosyoekonomik çevrede yetişmeleri, 
önceden yaşadıkları sarsıcı olaylar, sanal ortamda veya teknolojik araçlarla fazla vakit geçirmeleri yazma kaygısına neden olabilmektedir.

K.10. Eğitim, en başta eğitim, aile, sosyal çevre, sosyal aktivitesi yüksek olan çocuklar bakıyorsun hayalet dünyaları daha geniş daha çok şeyler yazabiliyorlar, farklı fikirler ortaya koyabiliyorlar, olaylara yaklaşımları, tek bir pencereden değil farklı pencerelerden bakabiliyorlar, olaylara uygun atasözleri, özdeyişler çok güzel hemen yerinde oturuyor, anılarını hemen akıllarına geliyor yazıyorlar.

K.7.Ya bir de şey var, mesela yazıyor çocuk doldurmuş etkinliği, doldurmuş bitmiş, hadi oku diyorsun, ben okumazsam olmaz mı diyor, ben de o zaman not vermesem olmaz mi, mecburen okuyor. Niye, bana gülerler mi, saçma oldu, yazdım ama güzel olmadı, yani mesela bu durumda ben sen bize otomatik olarak kilitlerin zaten diyorum. Sen yazdınsa en güzelini ortaya koymak için yazdın diyorum mesela.

Tablo 7. Katılımcıların "öğrencilerin yazma kaygılarının yazma performanslarına etkisi” hakkında görüşleri

\begin{tabular}{lccc}
\hline Yazma kaygısının performansa etkisi & Olumlu & $\begin{array}{c}f \\
\text { Olumsuz }\end{array}$ & Toplam \\
\hline Metin kalitesi & - & 17 & 17 \\
Yazma tutumu & - & 11 & 11 \\
Yazma becerisi & - & 7 & 7 \\
Başarı & - & 6 & 6 \\
Yaratıcılık & - & 6 & 6 \\
Hayal gücü & - & 5 & 5 \\
İfade yeteneği & - & 4 & 4 \\
Yazmaya başlayamama & - & 4 & 4 \\
Yazma beceri gelişimi & - & 4 & 4 \\
Özgüven & - & 3 & 3 \\
Çok yönlü düşünme & - & 2 & 2 \\
Dikkat & - & 1 & 1 \\
Toplam & - & $\mathbf{7 0}$ & $\mathbf{7 0}$ \\
\hline
\end{tabular}

Öğrencilerin yazma kaygılarının yazma performansına etkileri konusundaki görüşleri, yaşanılan yazma kaygısının yazma becerisini, yazma performansinı ve yazmaya yönelik tutumu olumsuz etkilediğini yansıtmaktadır. Yazma kaygısı yaşayan öğrencilerin, düşüncelerini doğru ve etkili şekilde kâğıda aktaramama, yazı düzenini sağlayamama gibi konularda sorun yaşadıkları, kaliteli metin üretemedikleri ve başarısızlık hissi yaşadıkları söylenebilir. Bu durumun özgüven ve yazmaya yönelik tutuma olumsuz yansımaları olabilir. Ayrıca öğrencilerin yazma kaygısı nedeniyle 
yazma işlemine başlamakta zorladığı söylenebilir. Tüm bu olumsuzlukların tamamı ise öğrencilerin yazmaya yönelik tutumlarını olumsuz yönde etkilemektedir.

K.4. Ya tabii yazma kaygısı olduğu zaman öğrenci bir sefer kendini tam olarak ifade edemiyor. Mesela ya beğenmezse şeklinde, ya beğenilmezse, ben nasıl yapacağım bunu, nasıl anlatacağım, çok zor bir şey. Yani genellikle bunu söyle yapıyorlar, ben anlamadım şeklinde çıkarıyorlar. Aslında anlayabilecekleri şey hocam, ben anlayamadım, şeklinde bir kaygı var.

K.12. Başarılı olamıyor, duygularını, düşüncelerini yeteri kadar anlatamıyor. Duygularını, düşüncelerini yeteri kadar anlatamadığ1 zaman öğrenci, yani nasıl söyleyeyim, bu sefer çevresine karşı içine kapanıyor, arkadaşlarından çekiniyor, hani acaba bana gülerler mi, benimle dalga geçerler mi, hani çok fazla boyutta değil ama tabii zaman zaman bunları yaşadığımız oluyor.

Tablo 8. Katılımcıların “öğrencilerin yazma kaygılarının yazma eğilimlerine yansımaları" hakkında görüşleri

\begin{tabular}{|c|c|c|c|}
\hline Yazma kaygısının eğilime yansımaları & Olumlu & $\begin{array}{c}f \\
\text { Olumsuz }\end{array}$ & Toplam \\
\hline Yazma isteği & 14 & 14 & 28 \\
\hline Düşük kayg1 & 10 & 4 & 14 \\
\hline Umursamazlık & - & 14 & 14 \\
\hline İçerik kalitesi & 3 & 9 & 12 \\
\hline Özgüven & 1 & 7 & 8 \\
\hline Yüksek kayg1 & - & 8 & 8 \\
\hline Biçim kalitesi & - & 4 & 4 \\
\hline Çok yönlü düşünme & - & 4 & 4 \\
\hline Kaygısızlık & - & 4 & 4 \\
\hline Yaratıcilık & - & 3 & 3 \\
\hline Yazmaya başlayamama & - & 2 & 2 \\
\hline Planlama becerisi & - & 1 & 1 \\
\hline Toplam & 28 & 74 & 102 \\
\hline
\end{tabular}

Öğrencilerin yazma kaygılarının yazma eğilimlerine etkisi hakkında en çok yazma isteğine değinilmiştir. Öğrencilerin çok düşük ve yüksek düzeydeki kaygıları yazma isteğini, yazma eğilimini, yazma becerisini olumsuz etkileyeceği söylenebilir. Öğrencilerin sıfır kaygı durumu içinde olmaları; sorumsuz davranmalarına ve yazmadan uzaklaşmalarına neden olduğu ve bu durumun umursamazlığa kadar ilerlediği belirtilmiştir. Ayrıca yüksek yazma kaygısı; düşünceleri düzenleyememe, planlama yapamama, 
yazmaya başlayamama sorunlarına neden olabilmektedir. Yüksek kaygının özgüven, yaratıcılık, çok yönlü düşünebilme ve planlama becerilerini, biçim ve içerik kalitesini olumsuz etkilediği söylenebilir. Bu durum, öğrencilerin başarısızlık hissine kapılmalarına, özgüven problemi yaşamalarına, yazmaya yönelik olumsuz tutum geliştirmelerine neden olabilmektedir.

K.8. Yani kaygı, düşük olsa daha iyi eserlerin çıkacağını düşünüyorum, yüksek olduğu zaman içinden gelenleri yazmayacaklarını, yazmak istediği şekilde değil, toplumun ya da ögretmenin nasıl yazmasını istiyorsa öyle yazacaktır diye düşünüyorum.

K.9. Yani tabii ki düşük kaygısı varsa daha güzel yazar, daha olumlu şeyler çıkar ortaya daha öğretmenin beklentisine hitap edilecek, hani metnin türüne uygun yazılar çıkıyor. E tabii ki orta kaygı da biraz daha idare eder bir yazı ortaya çıkıyor. Yüksek kâğı̆da gerçekten de başarısız oluyorlar. En azından yani metne uygun başlık bulmakta bile sıkıntı çekiyor.

Tablo 9. Katılımcıların "öğrencilerin yazma eğilimlerinin yazma performanslarına yansımaları” hakkında görüşleri

\begin{tabular}{|c|c|c|c|}
\hline Eğilimin performansa etkisi & Olumlu & $\begin{array}{c}f \\
\text { Olumsuz }\end{array}$ & Toplam \\
\hline Metin kalitesi & 21 & - & 21 \\
\hline Yazma alışkanlığı & 13 & - & 13 \\
\hline Yazma beceri gelişimi & 7 & - & 7 \\
\hline Yaratıcılık & 6 & - & 6 \\
\hline Akademik başarı & 4 & - & 4 \\
\hline Aktif katılım & 3 & - & 3 \\
\hline Özgünlük & 3 & - & 3 \\
\hline Üstbilişsel beceriler & 3 & - & 3 \\
\hline Yazarlik hedefi & 3 & - & 3 \\
\hline Kültürel gelişim & 2 & - & 2 \\
\hline Paylaşma & 2 & - & 2 \\
\hline Yetenek & 2 & - & 2 \\
\hline Toplam & 69 & - & 69 \\
\hline
\end{tabular}

Öğrencilerin yazma eğilimlerinin yazma performanslarına etkisi hakkındaki görüşlerin tamamı olumludur. Dolayısıyla yazma eğiliminin yazma beceri gelişimine, yazmaya yönelik tutuma, dil gelişimine olumlu yansıdığ1 ve yazma alışkanlığını desteklediği ifade edilebilir. Nitekim yazma eğiliminin yazma beceri gelişimini, üst düzey zihinsel becerileri, yaratıcılığ1, özgünlüğü, estetik ve kültürel gelişimi desteklediği belirtilmiştir. Yazma 
eğilimine sahip birey, daha özgür düşünebilecek, kendini daha doğru ve etkili ifade edebilecek, akademik başarısını artırabilecektir. Aynı şekilde akademik başarı ve yazma etkinliklerine katılımın yazma eğilimini artırdığ1 söylenebilir. Katılımcı görüşleri, yazma yeteneği olan öğrencilerin, yazma eğiliminin daha yüksek olduğu; yazma eğiliminin, yazma alışkanlığına katk1 sağladığı ve yazar olma isteğini artırdığı yönündedir. Ek olarak yazma eğiliminin yazma yeteneğini olumlu etkileyeceği söylenebilir.

K.3.Yani az önce bunu konuştuk aslında, ilgi ve istek yüksekse eğer tabii ki daha güzel, daha orijinal yazılar ortaya çıkabiliyor, yazma performansları da daha yüksek oluyor. Ama ilgi ve istek düşükse, yani zorla yazdırıyorsanız bir nevi, tabii ki öğrencide yazmış olmak için yazıyor ve çok başarılı sonuçlar elde edemiyor.

K.2. İstekler elbette olumlu etkileyecek yani öğrenci istiyorsa inanın ki siz öğretmen olarak, anne baba olarak ona engel olmaya çalışsanız bile o çocuk ne yapacak edecek onun bir yolunu bulup yazacaktır. Eğer bu duyguyu güçlü bir şekilde yaşıyorsa onun önüne geçmek mümkün değil, istediğini bir şekilde yeri gelir anne babadan ögretmenden gizli olarak da bu da ne yapabilir.

Tablo 10. Katılımcıların "öğrencilerin yazma eğilimlerini etkileyen faktörler" hakkında görüşleri

\begin{tabular}{|c|c|c|c|}
\hline Eğilim faktörleri & Olumlu & $\begin{array}{c}f \\
\text { Olumsuz }\end{array}$ & Toplam \\
\hline Öğretmen tutumu & 9 & 8 & 17 \\
\hline Anne-baba tutumu & 8 & 3 & 11 \\
\hline Sosyal pekiştireç & 11 & - & 11 \\
\hline Özgüven & 4 & 4 & 8 \\
\hline Yazma kaygisı & - & 7 & 7 \\
\hline Hazırbulunuşluk düzeyi & 3 & 3 & 6 \\
\hline Okuma alışkanlığı & 3 & 2 & 5 \\
\hline Sosyoekonomik düzey & 4 & 1 & 5 \\
\hline Akran değerlendirme & 2 & 2 & 4 \\
\hline Yetenek & 3 & 1 & 4 \\
\hline Sosyal medya ve teknoloji & - & 3 & 3 \\
\hline Yazma yarışması & 2 & - & 2 \\
\hline Eğitim sistemi & - & 1 & 1 \\
\hline Toplam & 49 & 35 & 84 \\
\hline
\end{tabular}

Öğretmenin özgürlükçü tutumu yazma eğilimini artırırken baskıcı tutumunun yazma eğilimini azalttığı konusuna en fazla değinilmiştir. Dil bilgisi, yazım gibi kuralların dayatılması, yazma eğilimini azaltabilmekte; 
öğrenci isteğini temel alan hoşgörülü tutum, özgür düşünebilmeyi, kaliteli metin üretimini desteklemektedir. Hatalardan ders çıkarılmasını sağlayan akran değerlendirme süreci, özgüven sarsıcı olayların yaşanmaması için iyi yönetilmelidir. Okuma-yazma konusunda ailenin örnek olması, uygun ortamı sağlamas1, doğru yönlendirmesi, cesaretlendirmesi yazma eğilimini destekleyebilmektedir. $\mathrm{Bu}$ doğrultuda yüksek sosyoekonomik çevrede yetişen öğrencilerin yazma eğilimlerinin yüksek olduğu söylenebilir. Öğrencilerin yazdıklarının beğenilmesi, takdir edilmesi yazma eğilimlerini desteklemektedir. Yüksek yazma kaygısı yaşayan ve hiç kaygı duymayan öğrencilerin yazma eğilimlerinin düşük olduğunu bildirilmiştir. Yazma konusunda yetenekli olan öğrencilerin yazma eğilimlerinin daha yüksek olduğu ifade edilmiştir. Ancak yazma, doğuştan gelen bir yetenek değil geliştirilebilen bir beceridir. Eğitim sisteminin ve teknolojik araçlarla fazla zaman geçirilmesinin öğrencilerin yazma gelişim ve eğilimlerine olumsuz yansıdığ 1 belirtilmiştir.

K.10. İşte dediğim gibi okuma isteği en başta, ailelerin eğitim durumu, kendinin işte $\mathrm{O}$ eğitime nasıl yaklaşımı önemli yani eğitim, okulda aldığı eğitim... Yani bir yazıdaki başarı, akademik başarısı varsa zaten diğerleri de geliyor. Tabii yetenek de önemli bir nevi, yeteneği olmayan bir ögrenciye çok bir şey de yazdıramıyoruz ama biraz bilgisi varsa, araştırmayı seven, meraklı öğrenciler daha başarılı oluyor.

K.3. Yazmaya olumlu yönde etkileyecek, hani çocuğun özel bir şimdi o konuda eğer bir yeteneği yazmaktan azalacaktır. Tabii dediğim gibi yani sınav sistemi Bunun üzerinde etkili, öğrenciler hep yazmadan ziyade işte bilgi edineyim, test çözeyim.

\subsubsection{Arkadaş ortamı bunda etkili midir sizce?}

Yani muhakkak etkilidir ama dediğim gibi alt sınıflarda biraz daha fazla etkili oluyor. Yani üste doğru çıkınca 7, 8 çok da şey değil hele 8'lerde hiç etkili olmaz. 
Tablo 11. Katılımcıların "öğrencilerin yazma eğilimlerinin artırılmasına yönelik uygulamaları” hakkında görüşleri

\begin{tabular}{lccc}
\hline Eğilimi destekleme & Olumlu & $\begin{array}{c}\boldsymbol{f} \\
\text { Olumsuz }\end{array}$ & Toplam \\
\hline Yazma yöntem ve teknikleri & 14 & 1 & 15 \\
Sınava dayalı sistem & - & 7 & 7 \\
Düzenli yazma alıştırmaları & 6 & - & 6 \\
Yönlendirme & 3 & 3 & 6 \\
Okuma alışkanlığı & 4 & - & 4 \\
Ön hazırlık çalışmaları & 4 & - & 4 \\
Pekiştireçler & 4 & - & 4 \\
Model oluşturma & 3 & - & 3 \\
Proje temelli yaklaşım & 3 & - & 3 \\
Şiir dinletisi & 3 & - & 3 \\
Zaman & - & 3 & 3 \\
Dönüt düzetme & 2 & - & 2 \\
Paylaşma & 1 & - & 1 \\
Toplam & $\mathbf{4 7}$ & $\mathbf{1 4}$ & $\mathbf{6 1}$ \\
\hline
\end{tabular}

Öğrencilerin en çok hikâye tamamlama ve serbest yazma yöntemlerini uygulamaktan hoşlandıkları için yazma eğilimini artırmak amacıyla bu yöntemlerin kullanıldığı belirtilmiştir. Ancak 2005'ten beri benimsenen süreç temelli yaklaşıma hiç değinilmemesi, yaklaşımın tam olarak uygulanamadığının yansımasıdır. Sınava dayalı sistem nedeniyle öğrencilerin temel becerilerini önemsemedikleri ifade edilmiştir. Çünkü sistem içerisinde başarı, yazma becerisi gibi dil becerilerini etkili kullanmak, gelişmiş üst düzey becerilere ve estetik duyarlığa sahip olmak değil girecekleri sınavlarda yüksek puanlar alarak kaliteli liselere yerleşmektir. Öğretmen ve ailelerinin olumlu model olmaları, yazmaya yönlendirmeleri ögrencilerin yazma eğilimlerine olumlu yansımaktadır. Yazma etkinliklerinin fazla zaman gerektirmesi, ders saatlerinin yetersiz olması gibi nedenlerin yazmayı olumsuz etkilediği bildirilmiştir. Öğretmenlerin dil bilgisi konularına öncelik vermek zorunda kaldıkları için yazma alıştırmalarının ikinci plana attıklarını belirtmeleri, sezdirmeye dayalı dil bilgisi yönteminin benimsenmediğinin yansımasıdır.

K.2. İşte onure edilmek, takdir edilmek, beğenilmek yapılan bir çalışmadan olayı illa yazmada şart değil bu çocuk bazında düşündüğümüz zaman yapılan bir şey çevresinde kabul gördüğü zaman, çocuk olmaya da gerek yok herkes için geçerli insani bir duygu bu, takdir edildiği zaman bir sonrakinde daha iyisini yapmaya.

K.6. Ben, normal bizim müfredatımıza ilave olarak eser inceleme saatleri ve seçme şiir saatleri düzenliyorum. Çocuklara bir hafta bir 
kitap oturuyorum, bir hafta bir kitap veriyorum onu 2 hafta içerisinde okuyup bir plan dâhilinde inceleyip yazıya geçiriyorlar ve sınıfta sunuyorlar. Aynı şekilde bir sonraki hafta da bir şair ya da konu veriyorum.

Tablo 12. Katılımcıların "öğrencilerin yazma kaygı ve eğilimlerine yönelik eklemek istedikleri” görüşleri

\begin{tabular}{|c|c|c|c|}
\hline \multirow{2}{*}{ Görüş ve öneriler } & \multicolumn{3}{|c|}{$f$} \\
\hline & Olumlu & Olumsuz & Toplam \\
\hline Okuma alışkanlığı & 9 & 2 & 11 \\
\hline Eğitim sistemi & - & 6 & 6 \\
\hline Öğretmen tutumu & 3 & 3 & 6 \\
\hline Pekiştireç & 6 & - & 6 \\
\hline Yazma yöntem ve teknikleri & 4 & - & 4 \\
\hline Paylaşma & 3 & - & 3 \\
\hline Hazırbulunuşluk & - & 2 & 2 \\
\hline Motivasyon & 2 & - & 2 \\
\hline Rol-model & 1 & 1 & 2 \\
\hline Kendini ifade edebilme & 2 & - & 2 \\
\hline Yazma alıştırması & 2 & - & 2 \\
\hline Yazma yarıșması & 1 & 1 & 2 \\
\hline Özgüven & 1 & - & 1 \\
\hline Yetenek & 1 & - & 1 \\
\hline Toplam & 35 & 15 & 50 \\
\hline
\end{tabular}

Okuma alışkanlığına sahip öğrencilerin, yazmaya daha eğilimli oldukları vurgulanmıştır. Eğitim sisteminin öğrencileri bir yarış içerisine sokarak kaygıyı artırdığı, test çözmeyi ön plana çıkarttığı, bazı temel becerilerin gelişimini engellediği söylenebilir. Öğretmenin özgürlükçü ve destekleyici tutumu, yazma yöntem ve tekniklerini etkili kullanması, öğrencilerin yazma tutumunu olumlu etkileyebilmektedir. İlkokul ögretmenlerinin temel dil becerilerine ve dil gelişimine gereken önemi vermemesi, öğrencilerin kaygılanmalarına ve yazmaktan kaçmalarına neden olabilmektedir. Yazma sonucunda alınan olumlu tepkilerin özgüveni ve yazma eğilimini desteklediği, yazma kaygısını azalttı̆̆ı söylenebilir. Öğrencilerin çevresinde yazma konusunda olumlu modellerin olması, yazma eğilimini desteklemektedir. Yazma yarışmalarının yazma eğilimini olumlu etkilediği, fakat öğrencilerin genel olarak yazma yarışmalarına katılmak istemedikleri ifade edilmiştir. 
K.12. Ya ben aslında şöyle düşünüyorum, burada biraz ilkokul öğretmenlerimize iş düşüyor. Şimdi ilkokulda 1'e başlıyor öğrenci, ben bu ilkokul öğretmenlerinde böyle çok büyük bir hırs görüyorum. Okumaya yazmaya geçirip orada bırakıyorlar, ondan sonra sadece matematik, o çocuk duygusunu düşüncesini nasıl anlatır diye böyle oturup da bir güzel bir gününü ona ayırsın mesela.

K.9. Yazma kaygısı ile ilgili yani çocukların ilgilerini artırıcı ne yapılabilir, yani güzel öğrencilere örnek metinler okutulabilir, gösterilebilir, okutulabilir. Yani ne bileyim, yani kaygıyı yenici başka ne olabilir ki?

11.9.1.Peki yazılan bir metnin bir yerde paylaşılması öğrenci için ilgiyi ve isteği artırıcı bir etken midir?

Olabilir, olabilir. Tabii ki mesela, beğendiğim bir yazıyı mesela o konuya uygunsa eğer yarışmalara katılması onların çok hoşuna gidiyor, derece falan olursa tabii ki populeriteleri de artıyor.

Çalışmanın nitel boyutuna ilişkin elde edilen bulgular NVivo programı kullanılarak şu şekilde boyutlandırılmıştır: 


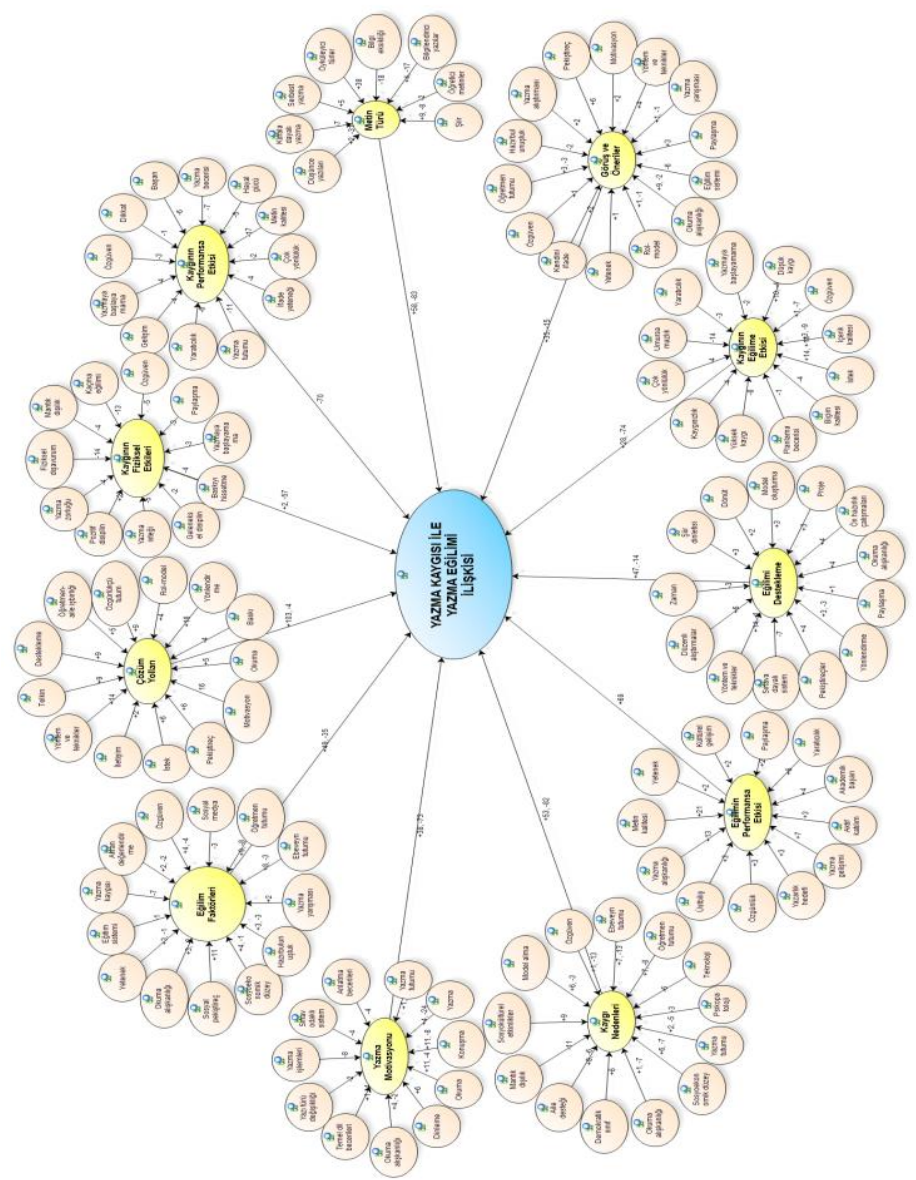

Şekil 1. Nitel verilere ilişkin model.

\section{TARTIŞMA VE SONUÇ}

Metin türü özelinde belirtilen görüşler doğrultusunda ortaokul öğrencilerinin yaşanmış ve yaşanabilir olaylardan hareketle, kahramanlar etrafinda şekillenen öyküleyici türde yazmaktan hoşlandıkları, hayal güçlerini etkin kullanabildikleri ve daha az kaygılandıkları söylenebilir. Öğrencilerin öyküleyici metinleri diğer türlere göre daha kolay anlayabildikleri belirlenmiştir (Sezgin Demir, 2014, s. 584). Öğrencilerin düşünceye dayalı ve bilgilendirici türlerde yazarken zorlandıkları, kayg1 seviyelerinin yükseldiği söylenebilir. Bu durumun, metin türlerine yönelik bilgi eksikliğinden kaynaklandığı ifade edilebilir. Yazma başarısının, 
yazılacak konu ve tür hakkında bilgi birikimine sahip olma ve bu bilgilerin etkin kullanımına bağlı olduğu belirlenmiştir (Bayat, 2014, s. 1130). Bilgilendirici metin oluştururken öğrencilerin karşı iddia geliştirmede zorlandıkları, yazılarını planlı bir şekilde yürüterek etkili şekilde sonlandıramadıkları belirtilmiş; öyküleyici metinlerde ise olay ve kişi kadrosunu oluşturmakta güçlük çektikleri ifade edilmiştir (Tiryaki, 2011, s. 136-139). Şiir türünde çeşitli ses tekrarları ve söz sanatlarıyla oluşturulan ahenkli söyleyişin çocukların ilgisini çektiği ancak bunları kullanarak şiirde etkili anlam oluşturmanın zorluğu vurgulanmıştır.

Öğrencilerin temel dil becerileri içerisinde en çok yazma konusunda motivasyon sorunu yaşadıkları belirtilmiştir. Öğrencilerin, diğer temel dil becerileri içinde en çok yazmada zorlandıkları belirtilmiştir (Baş ve Şahin, 2014, s.34). Benzer bir şekilde Pytash ve Li (2014, s. 24) yazmayı zor ve karmaşık bir beceri olarak tanımlamaktadır. Ayrıca yazma kaygısının, yazmaktan kaçma eğilimini artırdığı, yazma eğilimini olumsuz yönde etkilediği ifade edilebilir. Yazmada zorlanan bireyler, yüksek düzeyde kayg1 yaşamakta ve yazmaktan kaçınmaktadırlar (Daly ve Miller, 1975, s. 244). Öğrencilerin kaygılarının, dikkati toplama ve bilişsel işlemleri gerçekleştirmede problemlere neden olduğu belirlenmiştir (Eysenck, Derakshan, Santos ve Calvo, 2007, s. 348). Ayrıca okuma alışkanlığına sahip öğrencilerin yazma konusunda daha başarılı ve istekli oldukları vurgulanmıştır.

Katılımcılar, yazma kaygısı yaşayan öğrencilerin en çok titreme, baş ağrısı, mide bulantısı gibi fiziksel tepkiler gösterdiklerini, yazmaktan kaçtıklarını, özgüven eksikliği yaşadıklarını, yazma ilgi ve isteği duymadıklarını yazmaya başlama ve yazdıklarını paylaşma konusunda problem yaşadıklarını ifade etmişlerdir. Öğrencilerin yabancı dil derslerinde kalp çarpıntısı, unutkanlık, özgüven eksikliği, eleştirilme ve başarısızlık korkusu gibi kaygıdan kaynaklanan problemler yaşadıkları belirlenmiştir (Bhatti, Memon ve Pathan, 2016, s.32). Yazma kaygıs1; hayal kırıklığ1, değerlendirilme korkusu ve kaçınma gibi problemleri ortaya çıkararak yazma tutumunu olumsuz etkilemektedir (AslımYetiş, 2017, s. 73). Bu olumsuz durumların ortaya çıkmasında öğretmenin ve ailenin benimsediği disiplin anlayışının etkili olduğu çıkarsanabilir.

Yüksek kaygının; yazma isteğini, özgüveni, yaratıcılığı, planlama ve çok yönlü düşünme becerilerini olumsuz etkilemesi nedeniyle biçim ve içerik kalitesi düşük metinlerin ortaya çıkmasına neden olduğu belirtilmiştir. $\mathrm{Bu}$ durum ise özgüven, yazma isteği ve yazma eğilimini olumsuz etkileyerek yazma gelişimini engellemektedir. Düşük kaygının ise umursamazlığa neden 
olduğu ve yazma eğilimini azalttığı ifade edilmiştir. Sonuçlara paralel olarak ortaokul öğrencilerinin yaşadığı yüksek yazma kaygısının, planlama yapamama, dikkat dağınıklığı gibi problemlere ve yazmaktan kaçma davranışına; düşük yazma kaygısının yazmayı önemsememe ve yazma isteği duymamaya neden olduğu belirlenmiştir (S. Maden, Dincel, A. Maden, 2015). Benzer şekilde yüksek yazma kaygısının sözlü iletişim becerilerini olumsuz etkilediği tespit edilmiştir (Kean, Glynn ve Britton, 1987, s. 101). Yazma sonucunda yüksek başarı beklentisi olan öğretmen değerlendirmelerinin özgüven eksikliği, yüksek yazma kaygısı ve yazmaktan kaçma eğilimine neden olduğu tespit edilmiştir (Rezaei ve Jafari, 2014, s.1551).

Öğrencilerin yazma kaygıları; yazma becerilerini kullanmalarına, yazma gelişimlerine ve etkili ifade, yaratıcılık, hayal gücü, çok yönlü düşünme gibi becerilerine olumsuz olarak yansımaktadır. Yüksek yazma kaygısının metin kalitesini düşürdüğü, başarısızlık ve özgüven eksikliğine neden olduğu savunulmaktadır. Benzer şekilde yabancı dil kaygısının öğrencilerin yabancı dil gelişimlerini ve başarılarını engellediği tespit edilmiştir (Batumlu ve Erden, 2007, s. 36). Yazma kaygısının dil öğrenimini olumsuz etkilediği tespit edilmiştir (Dracopoulos ve Pichette, 2011, s. 110). Yazma kaygısı yaşayan öğrencilerin yazma çalışmaları yapılacak derslere girmek istemedikleri, yazma anında tedirginlik yaşadıkları ve yazmaya karşı olumsuz tutum geliştirdikleri belirlenmiştir (Selvi Demir, 2016, s.75). Yazma eğiliminin ise yazma kaygısının aksine yazma performansını geliştirdiği belirtilmiştir. Aynı şekilde yazma eğiliminin yazma performansını artırdığı ve yazma gelişimini olumlu etkilediği belirlenmiştir (McClenny, 2010, s. 61). Dolayısıyla buradan yazma kaygısı ile yazma eğiliminin kişinin bütünsel gelişimini ve yazma becerilerini zıt yönlerden etkilediği, yazma kaygısıyla yazma eğilimi arasında negatif yönlü bir ilişki olduğu çıkarsanabilir. Bu doğrultuda yapılan çalışmalarda yazma kaygısı ile yazma eğilimi arasında negatif yönde ilişki tespit edilmiştir (Çocuk, Yelken ve Özer, 2016, s. 341; İşeri ve Ünal, 2012, s. 73; Berk, 2014, s. 50).

Öğrencilerin yazma kaygılarını en çok anne, baba ve öğretmen tutumunun etkilediği ve yazma konusunda aile desteğinin, sosyoekonomik düzeyin ve demokratik sınıf tutumunun önemli olduğu belirtilmiştir. $\mathrm{Bu}$ etkenler, öğrencilerin özgüvenleri, mantık dişı otomatik düşünceleri, okuma alışkanlıkları ve yazma tutumları vb. faktörleri etkilediği gibi bu faktörler yazma kaygı düzeyi konusunda belirleyicidir. Öğretmenin anlayışl, demokratik, yapıcı tavırlar sergilemesi; ailenin çocuklarıyla etkili iletişim içerisinde olması öğrencilerin dil öğrenme tutumlarına olumlu yansıdığ tespit edilmiştir (Lababidi, 2016, s. 196). Benzer şekilde öğrenciye görelik 
ilkesinin göz ardı edilmesinin ve kırıcı eleştirilerin yazma kaygısını tetiklediği, yazma eğilimini azalttı̆̆ belirlenmiştir (Aş1lığlu ve Özkan, 2013, s.105). Yazma eğitiminde davranışçılığa dayanan yanlış uygulamaların kullanılması, öğrencilerin yazmayı kazanılması zor bir beceri olarak algılamalarına, yazmaya yönelik olumsuz tutum geliştirmelerine ve kaygılanmalarına neden olmaktadır (Karakoç Öztürk, 2012, s.61). Yabancı dil kaygısı üzerinde yapılan literatür çalışmasında yabancı dil kaygısının olumsuz değerlendirilme korkusu, öğretilen becerilerin zorluk düzeyi, olumsuz ögretmen davranışları ve sınav uygulamaları gibi etmenlerden kaynaklandığı belirtilmiştir (Aydın ve Zengin, 2008, s.89). Ayrıca sınav odaklı sistem ve yazı türü seçimi konusunda yaşanan sorunların yazma gelişimini engellediği ifade edilebilir. Öğretmen adaylarının yazma kaygilarının, yazma konusunda kendilerini yetersiz hissetmelerinden ve özgüven eksikliğinden kaynaklandığı bu duruma yazım ve noktalamaya fazla önem verilmesi, eleştirilme korkusu ve teste dayalı eğitim sisteminin neden olduğu belirtilmektedir (Selvi Demir, 2016, s. 76-78). Ayrıca ögrencilerin sanal ortamda fazla vakit geçirmeleri ve akranlarının yazma konusunda olumsuz model olmaları yazma kaygısını tetiklediği ifade edilebilir.

Öğrencilerin yazma kaygilarının aşılmasında en büyük sorumluluğun öğretmenlerin olduğu belirtilmiştir. Bu konuda öğretmenlerin öğrencileri doğru yönlendirerek desteklemeleri, birtakım pekiştireçlerle motivasyonlarını sağlamaları, etkili yöntem ve teknikleri kullanmaları, özgürlükçü bir tutum sergileyerek öğrencilerin yaratıcılıklarını desteklemeleri, yaşanan olumsuz durumlarda ve kaygı konusunda aileyle işbirliği içerisinde olmaları, kaygılanan öğrencileri telkinlerde bulunarak rahatlatmaları gerektiği belirtilmiştir. Serbest yazma çalışmalarının yazma kaygısının kontrol altına alınmasına fayda sağladığı belirtilmiştir (Karakoç Öztürk, 2012, s. 68; Tiryaki, 2011, s. 138). Ayrıca olumlu öğretmen-öğrenci iletişiminin önem taşıdığı, öğretmenin öğrencilerin isteğini göz önüne alarak yazma sürecini yönetmesi, yazma konusunda öğretmenin model olmas1 gerektiği vurgulanmıştır (Aslım Yetiş, 2017, s.83). Ancak kaygıyla baş edebilmede süreç temelli yaklaşımın etkisinden bahsedilmemiştir. Bu doğrultuda sürece dayalı yazma yaklaşımının metnin yapılanma sürecini ön hazırlık çalışmalarından paylaşma aşamasına kadar ele aldığından yazma kaygısını düşürdüğü yazma başarısını artırdığ 1 tespit edilmiştir (Bayat, 2014, s.1130). Akran değerlendirmenin yazma kaygısının azaltılmasında ve yazma becerilerinin gelişiminde etkili olduğu tespit edilmiştir (Jahin, 2012, s. 72). Öğrencilerin yazma kaygılarının azaltılmasında fiziksel aktivitelerin, nefes egzersizlerinin, okuma ve yazma çalışmalarının, öğretmenlerin bu konuda 
öğrencileriyle birebir ilgilenmesinin etkili olduğu bulunmuştur (Martinez, Kock ve Cass, 2011, s. 358). Yazma kaygılarının azaltılmasına yönelik çalışmalar öğrenme sürecini daha zevkli hâle getirerek öğrenme enerjisini ve özyeterlik inançlarını artırmaktadır (Piniel ve Csizér, 2013, s. 539).

Çalışmada öğretmen, anne ve babanın bilinçli tutumlarının bu konuda verilen sosyal pekiştireçlerin ve olumlu akran değerlendirmelerin öğrencilerin yazma eğilimlerini desteklediği belirtilmiştir. Bir başka araştırmada akran geri bildiriminin öğretmen adaylarının yazma kaygılarını düşürdüğü, yazma eğilimlerini artırdığı belirlenmiştir (İşeri ve Ünal, 2012, s.74). Yüksek yazma kaygısı; düşük sosyoekonomik çevrede yetişme, özgüven eksikliği, eksik hazırbulunuşluk, kitap okumama sosyal medya ve teknolojiyle fazla vakit geçirme gibi etmenlerin yazma eğilimini düşürdüğü söylenebilir. Benzer şekilde öğrencilerin ilgi alanları, duyguları, öz düzenlemeleri, amaçları ve inançlarının yazma eğilimini etkilediği vurgulanmaktadır (Piazza ve Siebert, 2008, s. 276). Öğrencilerin fizyolojik, psikolojik ve sosyal yönlerinin yazma eğilimlerini etkilediği, sağlıklı yaşam tarzına sahip olmayan, duygusal olarak kendini iyi hissetmeyen mutsuz öğrencilerin yazmaya yönelik olumsuz tutum sergiledikleri belirlenmiştir (Bartscher, Lawler, Ramirez ve Schinault, 2001, s. 47). Yaratıc1 yazma etkinliklerinin öğrencilerin yazma eğilimlerinin artırılmasında etkili olduğu tespit edilmiştir (Avc1, 2013, s. 70).

Katılımcılar öğrencilerin yazma eğilimlerinin artırılması adına yazma yöntem ve tekniklerini kullanarak düzenli yazma alışkanlıkları gerçekleştirdiklerini, ön hazırlık çalışmalarına önem verdiklerini, proje temelli yaklaşım benimsediklerini, şiir dinletisi ve okuma etkinlikleri yaptıklarını belirtmişlerdir. $\mathrm{Bu}$ doğrultuda sınıf öğretmenleri üzerinde gerçekleştirilen araştırmada katılımcıların yazma stratejileri hakkında yeterli bilgiye sahip olmadıkları ve öğrencilerine yazma stratejilerini ögretemedikleri, onları yönlendiremedikleri bu durumun hem öğrencilerin hem öğretmenlerin yazma becerilerine olumsuz yansıdığı ifade edilmektedir (Erdoğan, 2017, s. 672). Ancak eğitim sistemi sinava dayalı olduğundan özellikle 7 ve 8 . sınıf öğrencilerinin yazma eğilimleri ve gelişimleri adına çalışmalar gerçekleştirilemediği, öğrencilerin de yazma çalışmaları yerine test çözme eğiliminde oldukları vurgulanmıştır. Ortaokul öğrencileri içerisinde 7 ve 8 . sınıfların özellikle 8. sınıfların yazma kaygılarının daha yüksek olduğu belirlenmiştir (Aş1lığlu ve Özkan, 2013, s.105). Öğrencilerin yazma becerilerinin yazma çalışmaları sonucunda geliştiğini, bu durumun öğrencilerin yazmaya yönelik tutumlarına olumlu yansıdığı belirlenmiştir (Bartscher ve ark, 2001, s. 41). Ayrıca katılımcılar, yazma etkinliklerinin 
fazla zaman alması nedeniyle yeterince uygulama yapamadıklarını, her öğrenciye dönüt düzeltme veremediklerini belirtmişlerdir.

\section{ÖNERILER}

Öğretmen ve ailenin öğrencilerin yazma ve bütünsel gelişimleri için demokratik, anlayışlı, ılımlı ve kapsayıcı olmaları gerektiği konusunda bilinçlendirilmesi gerekmektedir. Bu amaçla okul rehber öğretmenlerinden yardım istenebilir. Öğretmenlerin sezdirme yöntemi ve süreç temelli yaklaşımı uygulamadıkları belirlenmiştir. Öğrenciyi temel alan yapılandırmacı yaklaşım konusunda öğretmenler bilinçlendirilmeli, öğrenci tutumunu olumsuz etkileyen davranış̧̧ı ve geleneksel dil öğretim yaklaşımlarının terk edilmesi sağlanmalıdır.

Öğrencilerin özgüvenleri adına yazma sonucunda beğenilme ve takdir edilme ihtiyaçları karşılanmalı, hataları kırıcı olmadan fark ettirilerek düzeltmeleri sağlanmalıdır. Öğrencilerin yazmada yetersiz hissetmelerine neden olabilecek bilgi ve beceri eksikliklerinin tamamlanması adına yazma teknikleri kullanılmalı, öğrenciler yönlendirilmeli ve bilinçlendirilmelidir. Ayrıca yazma kaygısıyla baş edebilmede çeşitli nefes ve zihinsel egzersizler öğrencilere öğretilmeli, yazma kaygısının aşılabileceği gösterilmelidir. Öğretmen ve ailenin okuma alışkanlığının kazandırılması adına işbirliği içinde olmaları, öğrencileri okumaya yönlendirmeleri gerekmektedir.

Öğrencilerin yazma kaygı ve eğilimlerine yönelik görüşlerinin alınması konuya hem öğretmen hem öğrencilerin gözünden bakmaya yardımcı olacaktır. Bu doğrultuda öğrencilerin yazma becerisini olumsuz etkileyen farklı psikolojik durumları ele alınabilir. Ayrıca öğretmenlerin yazma yöntem ve tekniklerini uygulama konusundaki yeterliliklerinin belirlenmesi de yazma gelişimine katkı sağlayacaktır.

\section{Teşekkür ve Bilgilendirme}

$\mathrm{Bu}$ çalışma, Doç. Dr. Sezgin Demir danışmanlığında Firat Üniversitesi Eğitim Bilimleri Enstitüsü Türkçe Eğitimi Bilim Dalında yürütülen ve $2018 \mathrm{Kasım}$ ayı içerisinde tamamlanan "Öğrencilerin Yazma Kaygılarının Yazma Eğilimleriyle İlişkisi” adlı yüksek lisans tezinden hareketle hazırlanmıştır. Araştırma süreci boyunca zamanını ve desteğini esirgemeyen çok kıymetli danışman hocam Doç. Dr. Sezgin DEMİR'e sonsuz teşekkürlerimi sunuyorum. Aynı zamanda çalışma, 18-20 Nisan 2019 tarihinde Alanya Alaaddin Keykubat Üniversitesinde gerçekleştirilen VI. 


\section{ASOS Congress Uluslararası Eğitim Bilimleri Sempozyumu'nda sözlü bildiri olarak sunulmuştur.}

\section{KAYNAKLAR}

Akyol, H. (2015). Türkçe ilkokuma yazma öğretimi. Ankara: Pegem Akademi.

Aşılığlu, B. ve Özkan, E. (2013). Ortaokul öğrencilerinin yazma kaygılarının bazı değişkenler açısından incelenmesi: Diyarbakır örneği. International Journal of Social Science, 6(6), p. 83-111.doi: http://dx.doi.org/10.9761/JASSS1527

Aslım Yetiş, V. (2017). Sources of Writing Anxiety: A Study on French Language Teaching Students. International Education Studies, 10(6), 72-86. doi: https://doi.org/10.5539/ies.v10n6p72

Avcı, A. S. (2013). Yaratıcı yazma etkinliklerinin 8. sınıf öğrencilerinin yazma ĕgilimleri ve yazma kaygılarına etkisi. Yayımlanmamış yüksek lisans tezi. Niğde Üniversitesi, Eğitim Bilimleri Enstitüsü, Niğde.

Aydın, S. ve Zengin, B. (2008). Yabancı dil öğreniminde kayg1: Bir literatür özeti. Journal of Language and Linguistic Studies, 4(1), 81-94.

Bartscher, M. A., Lawler, K. E., Ramirez, A. J., \& Schinault, K. S. (2001). Improving Student's Writing Ability through Journals and Creative Writing Exercises. Unpublished masters thesis. Saint Xavier University, Chicago.

Baş, G. ve Şahin, C. (2013). İlköğretim öğrencilerinin yazma eğilimlerinin farklı değişkenler açısından incelenmesi. Sakarya Üniversitesi Ĕ̈itim Fakültesi Dergisi, 3(1), 32-42.

Batumlu, D. Z. ve Erden, M. (2007). Yıldız Teknik Üniversitesi yabancı Diller Yüksek Okulu hazırlık öğrencilerinin yabancı dil kaygıları ile İngilizce başarıları arasındaki ilişki. Ĕgitimde kuram ve uygulama, 3(1). 24-38.

Bayat, N. (2014). Sürece dayalı yazma yaklaşımının yazma başarısı ve kaygısı üstündeki etkisi. Kuram ve Uygulamada Ĕ̈itim Bilimleri, 14(3), 1123-1141.

Berk, R. R. (2014). Altı, yedi ve sekizinci sınıf öğrencilerinin yazma kaygl ve ĕgilimlerinin karşılaşıtırılması. Yayımlanmamış yüksek lisans tezi. Niğde Üniversitesi, Eğitim Bilimleri Enstitüsü, Niğde.

Bhatti, N., Memon, S., \& Pathan, H. (2016). Investigating the Perceptions of Pakistani English Language Learners on Language Learning Anxiety in EFL Classroom. Advances in Language and Literary Studies, 7(5), p. 23-34. doi: http://dx.doi.org/10.7575/aiac.alls.v.7n.5p.23

Bilgin, N. (2014). Sosyal bilimlerde içerik analizi: teknikler ve örnek çalışmalar. Ankara: Siyasal Kitabevi.

Büyüköztürk, Ş., Çakmak, E. K., Akgün, Ö. E.. Karadeniz, Ş. ve Demirel, F. (2014). Bilimsel araştırma yöntemleri. Ankara: Pegem Akademi.

Cemiloğlu, M. (2001). İlköğretim okullarında Türkçe öğretimi: yeni programa uyarlanmış. Bursa: Alfa Aktüel Yayınları.

Çocuk, H. E., Yelken, T. Y., \&Ö zer, Ö. (2016). The relationship between writing anxiety and writing disposition among secondary school students. Eurasian Journal of Educational Research, 16(63). 
Creswell, J. W. (2016a). Araştırma deseni: nitel, nicel ve karma yöntem yaklaşımları. (Çev. Ed. S. B. Demir). Ankara: Eğiten Kitap.

Creswell, J. W. (2016b). Nitel araştırma yöntemleri: beş yaklaşıma göre nitel araştırma yöntemleri. (Çev. Ed. M. Bütün ve S. B. Demir). Ankara: Siyasal Kitabevi.

Creswell, J. W. ve Plano Clark, V. L. (2015). Karma yöntem araştırmaları: tasarımı ve yürütülmesi. (Çev. Ed. Y. Dede ve S. B. Demir). Ankara: Anı yayıncılık.

Daly, J. A. \& Miller, M. D. (1975). The empirical development of an instrument to measure writing apprehension. Research in the Teaching of English, 9(3), 242-249.

Demir, Selvi. (2016). Türkçe ögretmen adaylarının yazma kaygısı düzeyleri ve nedenleri: bir karma yöntemli yaklaşım. Yayımlanmamış yüksek lisans tezi. Yüzüncü Yı1 Üniversitesi. Eğitim Bilimleri Enstitüsü. Van.

Demir, Sezgin. (2014). Ortaokul (6. 7. 8) Türkçe Ders Kitaplarındaki Metinlerin Anlam Yapısı ile Bunlara İlişkin Öğretmen Görüşleri ve Öğrencilerin Özyeterlik Alglları. Yayımlanmamış doktora tezi. Fırat Üniversitesi. Eğitim Bilimleri Enstitüsü. Elazı̆̆.

Dracopoulos, E. \& Pichette, F. (2011). Second language writing anxiety, computer anxiety, and performance in a classroom versus a web-based environment. Studies in Second Language Learning and Teaching 4(1). 111-117.

Erdoğan, Ö. (2017). Sınıf öğretmenlerinin yazma stratejilerini kullanma durumlarına ilişkin görüşleri. Abant İzzet Baysal Üniversitesi Eğitim Fakültesi Dergisi.

Eysenck, M. W., Derakshan. N., Santos. R. and Calvo. M. G. (2007). Anxiety and cognitive performance: attentional control theory. Emotion. 7(2). 336.

İşeri, K. ve Ünal, E. (2010). Yazma Eğilimi Ölçeği 'nin Türkçeye uyarlanması. Eğitim ve Bilim. 35(155).

İşeri, K. ve Ünal, E. (2012). Türkçe öğretmen adaylarının yazma kaygı durumlarının çeşitli değişkenler açısından incelenmesi. Mersin Üniversitesi Ĕ̆itim Fakültesi Dergisi, $8(2)$.

Jahin, J. H. (2012). The Effect of Peer Reviewing on Writing Apprehension and Essay Writing Ability of Prospective EFL Teachers. Australian Journal of Teacher Education, 37(11), 60-84.

Karakoç Öztürk, B. (2012). İlköğretim ikinci kademe öğrencilerinin yazma kaygılarının çeşitli değişkenler açısından incelenmesi. Çukurova Üniversitesi Sosyal Bilimler Enstitüsü Dergisi, 21(2).

Karasar, N. (2009). Bilimsel araştırma yöntemi. Ankara: Nobel Yayıncılık.

Kean, D. K., Glynn, S. M., \& Britton, B. K. (1987). Writing persuasive documents: The role of students' verbal aptitude and evaluation anxiety. The Journal of Experimental Education, 55(2), p. 95-102. doi: https://doi.org/10.1080/00220973.1987.10806440

Lababidi, Y. (2016). By Fire: Writings on the Arab Spring. World Literature Today, 90(5), 97-98.

Maden, S., Dincel, Ö. ve Maden, A.(2015). Türkçeyi Yabancı Dil Olarak Öğrenenlerin Yazma Kaygıları. Uluslararası Türkçe Edebiyat Kültür Eğitim Dergisi, 4(2), 748769.

Martinez, C. T., Kock, N., \& Cass, J. (2011). Pain and pleasure in short essay writing: Factors predicting university students' writing anxiety and writing self-efficacy. Journal of 
H. Deniz ve ark. / Eğitim Fakültesi Dergisi 32 (2), 2019, 497-526

Adolescent \& Adult Literacy, 54(5), 351-360. doi: https://doi.org/10.1598/JAAL.54.5.5

McClenny, C. S. (2010). A disposition to write: Relationships with writing performance. Unpublished PhD dissertation, The Florida State University, College of Education.

Miles, M. B. ve Huberman, A. M. (2016). Genişletilmiş bir kaynak kitap: nitel veri analizi. (S. A. Altun. A. Ersoy Çev.). Ankara: Pegem Akademi.

Par, A. H. (2007). Planlı yazma sanatı: kompozisyon. İstanbul: Serhat Yayınları

Patton MQ, 2014. Nitel araştırma ve değerlendirme yöntemleri. (Çev. Ed. Bütün M ve Demir SB), Ankara: Pegem Akademi.

Piazza, C. L. \& Siebert, C. F. (2008). Development and validation of a writing dispositions scale for elementary and middle school students. The Journal of Educational Research, 101(5), p. 275-286. doi: https://doi.org/10.3200/JOER.101.5.275-286

Piniel, K. \& Csizér. K. (2013). L2 motivation. anxiety and self-efficacy: The interrelationship of individual variables in the secondary school context. Studies in second language learning and teaching. 3(4), p. 523-550.

Pytash, K. E., \& Li, J. (2014). The writing dispositions of youth in a juvenile detention center. Journal of Correctional Education, 65(3), p. 24-42.

Rezaei, M., \& Jafari, M. (2014). Investigating the levels, types, and causes of writing anxiety among Iranian EFL students: A mixed method design. Procedia-Social and Behavioral Sciences, 98, 1545-1554. doi: https://doi.org/10.1016/ j.sbspro.2014.03.577

Sönmez, V. ve Alacapınar. F. G. (2016). Sosyal bilimlerde ölçme aracı hazırlama. Ankara: Anı Yayıncilık.

Sundem, G. (2007). Improving student writing skills: practical strategies for succesful clasrooms. Corinne Burton, M.A.Ed, Shell Education.

Tiryaki, E. N. (2011). Üniversite öğrencilerinin tartışmacı metin yazma becerileri ile yazma kaygısı ve eleştirel düşünme becerileri. Yayımlanmamış Yüksek Lisans Tezi, Mustafa Kemal Üniversitesi, Hatay.

Türnüklü, A. (2000). Eğitimbilim araştırmalarında etkin olarak kullanılabilecek nitel bir araştırma tekniği: görüşme. Kuram ve Uygulamada Eğitim Yönetimi. 6(4). s. 543559.

Williams, J. D. (2003). Preparing to teach writing: Research, theory, and practice. London: Lawrence Erlbaum Associates.

\section{EXTENDED ABSTRACT}

The writing process involves the effective use of ways of writing, researching and acquiring knowledge that requires extensive knowledge and skills, and supporting students' curiosity and exploration feelings, and research skills. Each step of the writing process involves intensive cognitive processes and the simultaneous use of various cognitive, affective and mental skills at the time of writing support brain development significantly. Writing anxiety is one of the factors that negatively affect writing education prevents students' writing skill 
development. Writing tendency is the rate of use of skill by writing interest and desire. Therefore, the acquisition, development and habit of writing skills are related to writing anxiety as well as writing disposition. The current study aimed to determine the opinions of Turkish teachers about writing anxiety and tendencies of students. To this main aim, the study set out to clarify the reasons, effects and relationship between writing anxiety and tendency, and anxiety situations of the students according to the text type. The research was designed as a qualititative, phenomenological study, and data were analyzed by content analysis method. The study group was determined on a voluntary basis by means of progressive and purposive sampling method, consists of 12 Turkish teachers working in Elazığ city center. In the face-to-face interviews a semi-structured interview form which was developed by the researchers was used, and the tabulated results according to the frequency distributions were interpreted according to the literature. Students' writing anxiety refleceds negatively on skills such as effective expression, creativity, imagination, multi-dimensional thinking and writing development. It has been argued that high writing anxiety decreases the quality of the product obtained as a result of writing and causes failure and lack of self-confidence. Similarly, writing anxiety has been also found to adversely affect language learning (Dracopoulos \& Pichette, 2011). Moreover, students who are anxious about writing do not want to take courses in writing studies, they experience uneasiness in writing and have a negative attitude towards writing (Selvi Demir, 2016). Writing tendency positively affects all these situations which affect the writing anxiety negatively and improves writing performance. Moreover, it has been found that writing tendency increased writing performance and positively affected writing development (McClenny, 2010). Therefore, it can be deduced that writing anxiety and writing tendency affect one's development and writing skills in opposite directions, and that there is a negative relationship between writing anxiety and writing tendency. The participants stated that the most important task in overcoming writing anxiety of the students fell upon the teachers. In this respect, it is stated that the teachers should support the students correctly, provide the motivation with some reinforcements, use the effective methods and techniques and provide the students to use their creativity. It was emphasized that positive teacher-student communication is important, and that the teacher should manage writing process considering the students' wishes (AslımYetiş, 2017). It has been stated that the participants, teachers, parents 'conscious attitudes, social reinforcements and positive peer assessments supported students' writing tendencies. It has been determined that peer feedback decreased the writing anxiety of pre-service teachers and increased writing tendencies (İşeri \& Ünal, 2012). Participants stated that they have been doing regular writing exercises by using writing methods and techniques in order to increase their writing tendencies. In this respect, it can be argued that the participants did not have enough knowledge about writing strategies, which negatively reflected the writing skills of both students and teachers (Erdoğan, 2017). However, because the education system was based on the exam, it was emphasized that especially 7 th and $8^{\text {th }}$-grade students were not able to carry out studies on the writing tendencies and development, and that students tended to solve tests rather than doing writing activities. 
It can be said that the oppressive authoritarian family or teacher attitudes trigger writing anxiety of students and decreases writing tendencies. In this respect, the teacher and the family should be aware of the need to be democratic, understanding, moderate and inclusive for the students' writing and holistic development. It has been emphasized that lack of confidence triggered writing anxiety and reduced writing tendency. In this direction, students 'needs for appreciation must be met for the sake of the students' self-confidence, and their errors should be addressed with constructive feedback. In this regard, teachers should have group activities to ensure that students are open to criticism and empathic. Students with effective reading habits are more prone to writing and are less anxious. The teacher and the family should cooperate to help students develop effective reading habits. In addition, the love of books should be inculcated while considering the wishes of the student. In conclusion, it can be said that students whose parents are illiterate and who do not participate in cultural activities have low writing tendencies and high writing anxiety. In order to support students' literacy skills, illiterate parents should be encouraged to learn how to read and write. In addition, children who are unable to participate in cultural activities due to socioeconomic reasons should be guided by teachers and studies should be conducted in this direction. 